\title{
A third-order multi-point boundary value problem at resonance with one three dimensional kernel space
}

\author{
XiAojie Lin, Bensheng ZhaO and Zengui Du
}

\begin{abstract}
.
This paper deals with a third order nonlinear differential equations with multi-point boundary conditions. By using the coincidence degree theory, we establish some existence results of the problem at resonance under some appropriate conditions. The emphasis here is that the dimension of the linear operator is equal to three. We also give an example to demonstrate our results.
\end{abstract}

Acknowledgements. This work is supported by the Natural Science Foundation of China (Grant No. 11071205 and 11101349), and partially supported by the Natural Science Foundation of Jiangsu Province (Grant No. BK2011042), the Natural Science Foundation of Jiangsu Education Department (11KJB110013) and Qing Lan Project.

\section{REFERENCES}

[1] Du, Z., Solvability of functional differential equations with multi-point boundary value problems at resonance, Comput. Math. Appl., 55 (2008), 2653-2661

[2] Du, Z., Lin, X. and Ge, W., On a third-order multi-point boundary value problem at resonance, J. Math. Anal. Appl., 302 (2005), 217-229

[3] Du, Z. and Meng, F., Solutions to a second-order multi-point boundary value problem at resonance, Acta Math. Sci., 30 (2010), 1567-1576

[4] Kosmatov, N., A multi-point boundary value problem with twscritical conditions, Nonlinear Anal., 65 (2006), $622-633$

[5] Ge, W., The boundary value problems of nonlinear ordinary differential equations, Science Press, Beijing, 2007 (in Chinese)

[6] Lian, H., Pang, H. and Ge, W., Solvability for second-order three-point boundary value problems at resonance, J. Math. Anal. Appl., 337 (2008), 1171-1181

[7] Liang, R., Ren, L. and Zhao, Z., Existence of solutions for a multi-point boundary value problems with three dimension kernel at resonance, Chin. Quart. J. Math., 26 (2011), 138-143

[8] Lin, X. and Liu, W., A nonlinear third-order multi-point boundary value problem in the resonance case, J. Appl. Math. Comput.,29 (2009), 35-51

[9] Liu, B. and Zhao, Z., A note on multi-point boundary value problems, Nonlinear Anal., 67 (2007), 2680-2689

[10] Ma, J. and Yang, Y., Existence result for a singular nonlinear boundary value problems at resonance, Nonlinear Anal., 68 (2008), 671-680

[11] Mawhin, J., Topological degree methods in nonlinear boundary value problems, NSFCBMS Regional Conference Series in Mathematics, American Mathematical Society, Providence, RI, 1979

[12] Xue, C., Du, Z. and Ge, W., Solutions for m-point boundary value problems of third-order ordinary differential equations at resonance, J. Appl. Math. Comput., 17 (2004), 229-244

[13] Yang, L. and Shen, C., On the existence of positive solution for a kind of multi-point boundary value problem at resonance, Nonlinear Anal., 72 (2010), 4211-4220

Received: 14.04.2012; In revised form: 03.10.2012; Accepted: 12.12 .2012

2010 Mathematics Subject Classification. 34B15.

Key words and phrases. Multi-point boundary value problem, coincidence degree theory, resonance.

Corresponding author: Zengji Du; duzengji@163.com 
JIANGSU NORMAL UNIVERSITY

SCHOOL OF MATHEMATICS AND STATISTICS

XUZHOU, JiANGSU 221116, P. R. CHINA

E-mail address: linxiaojie1973@163.com

E-mail address: duzengji@163.com

E-mail address: zhaobensheng.1@163.com 